\title{
L-D STEELMAKING AT MID-1967
}

\author{
by J. K. Stone
}

Current information indicates that installed L-D steelmaking capacity in the U. $S$. is now 43 million annual tons and can be expected to reach 50 million tons by Jan., 1968. Announced expansion programs will further increase capacity to 65 million tons by early 1970. Total capacity in operation by 1970 will exceed this amount, however, because of several new plants that have not yet been announced. The accompanying table lists the announced L-D plants in the U. S. that are in operation and under construction, or planned.

Worldwide capacity of L-D steel plants is also growing at a rapid rate. Installed annual capacity reached about 140 million tons at the beginning of 1967 , and is expected to approach 250 million tons by early 1970 .

Present operating rates and projected start-ups of L-D plants in 1967 indicate that about 42 million tons of raw steel will be produced by the process in the U. S. this year. Fig. 1 shows past and projected steel production in the U. S. according to the various processes. L-D basic oxygen steel production was first reported in 1955. In 1959, L-D output exceeded bessemer production, and it surpassed electric furnace output in 1964. Projections by Kaiser Engineers Div. of Kaiser Industries Corp., indicate that basic oxygen ( $\mathrm{L}-\mathrm{D}$ and Kaldo) steel production will exceed open hearth before 1970. In 1970, the L-D Process is expected to account for about half of the raw steel produced in the U. S.

\section{Early Obsolescence}

One significant step in the phenomenal growth of L-D steel production is that even relatively modern open hearth shops are being displaced by low cost, highly productive L-D plants. An example is the start-up of Granite City Steel Co.'s L-D plant. Production from this plant will ultimately replace the output of seven large open hearths that were constructed during and after World War II. Up to this time, open hearths replaced by the L-D Process were built before World War II. A total of at least 11 open hearth shops has been rendered obsolete and demolished, or reduced to standby status. A continuation of this trend is

J. K. Stone is manager, Steel Plants Development, Kaiser Engineers Div. of Kaiser Industries Corp., Oakland, Calif. expected to reduce open hearth production in 1969 to about the level of the increasing L-D production.

\section{Larger Furnaces}

Some companies are now erecting their second or third L-D plant. Thus, another factor in the growth of L-D capacity is the eagerness of each company that installs an additional plant to gain the advantages achieved in the previous plants. Also of major interest has been the increase in furnace and heat size. In 13 years, heats have increased from

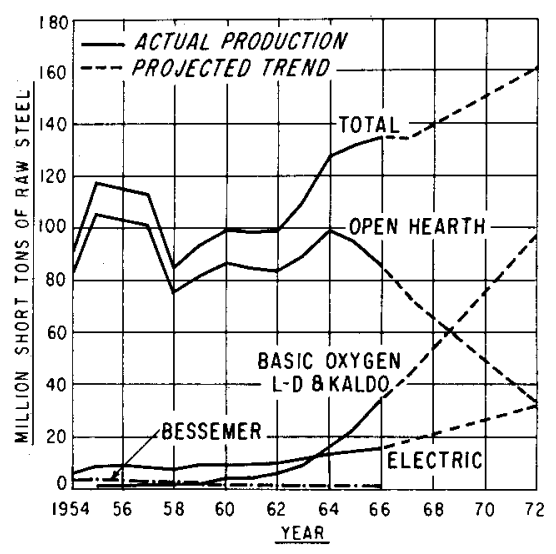

Fig. 1-Steel production by processes in the U.S.

under 50 tons to the point where furnaces under 150 tons are seldom built. Some of the increase in heat size has come from overcharging, but most of it can be attributed to the installation of larger furnaces.

The imminent retirement of shops started up in 1957 at Aliquippa, Pa., and in 1954 at Trenton, Mich., marks the start of another significant round in the spread of the technology. We now are seeing the partial retirement and replacement of the first two plants installed in the U. S. It is also significant that each of the new shops is designed to furnish metal for a continuous casting plant.

The earliest continuous casting machines were usually installed in non-integrated plants where steel was supplied by an electric furnace. Wisconsin Steel Div., International Harvester Co. began a billet casting machine to use the output of their L-D plant, and Jones \& Laughlin Steel Corp. is building a similar machine at Aliquippa. McLouth Steel Corp., U.S. Steel Corp., and Weirton Steel Div., National Steel Corp. are experimenting, installing, and operating L-D and continuous casting combinations for making slabs from rimmed steel or some suitable substitute for it.

The industry will watch closely the results at Gary, Weirton, and Trenton to see if the special features built into these plants will enable the continuous casting of rimmed or pseudo-rimmed steel. If so, the natural combination of L-D and continuous casting, so apparent on killed steels, will be given further impetus for casting the large tonnage of rimmed steel now made in the L-D and cast into ingots. The results will influence the future planning for soaking pits and primary mills.

\section{Growth of Alloy Steel}

Current production of AISI alloy steels now constitutes $6 \%$ of all basic oxygen steel, while $9 \%$ of open hearth steels are alloy grades. The quantity of alloy steel made in basic oxygen furnaces has risen from virtually none in 1960 to over 2 million tons in 1966. It will probably reach 2.5 million tons in 1967. The increase in use of the process for high carbon (above $0.30 \%$ ) steels can also be expected to increase from the present $10 \%$, as more L-D plants are installed in conjunction with continuous casting machines. The developing association of continuous casting and L-D steelmaking should tend to increase the output of killed, alloy, and high carbon grades of steel in the L-D furnace, because of the ability to continuous cast these.

Up to this time, production of stainless steels has been experimental in the U. S., Austria, and Japan, and there has been limited commercial production in West Germany. Crucible Steel Co. has announced that its Midland, Pa. plant will make stainless steel in top-blown oxygen converters from special chromiumbearing hot metal produced in a blast furnace.

Methods of using scrap to replace part of the hot metal requirements of the basic oxygen processes are coming into use. The scrap melting cupola at Allegheny Ludlum Steel Corp. is now probably responsible for the highest proportion of total scrap consumption in making basic oxygen steel. Commercial use has been made of scrap preheating in the operating L-D furnace with natural gas at Wisconsin Steel. Calcium carbide-though a more costly source of heat than hydrocarbon fuels-has been utilized at several plants on a temporary basis to com-

(To page 36 ) 


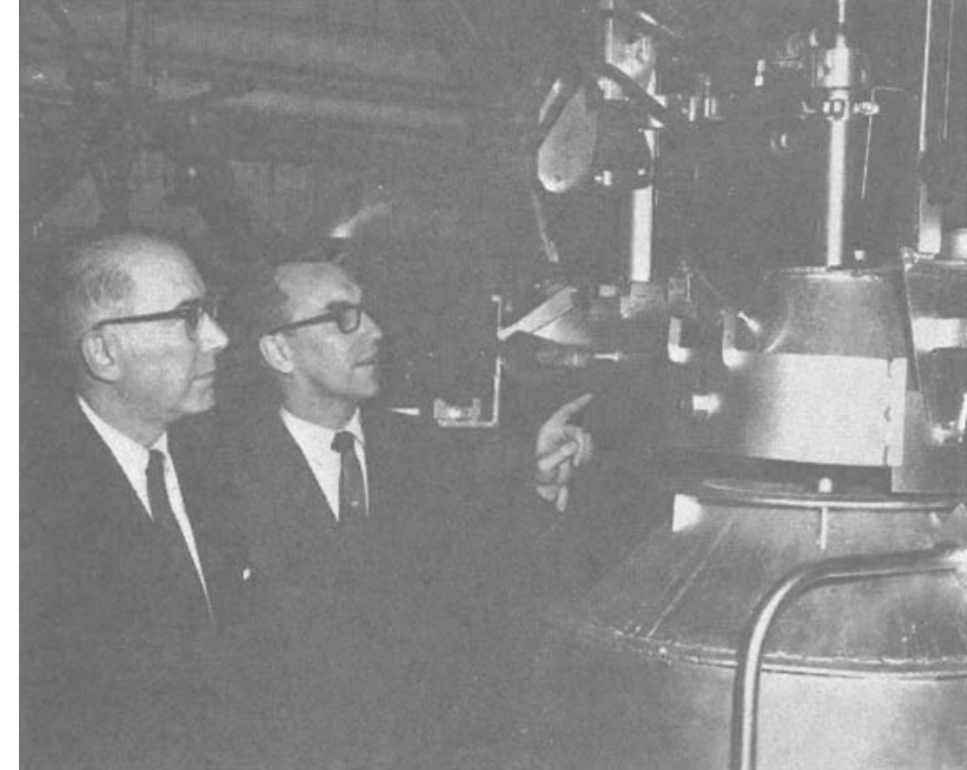

1966 Herty Award winners, Edward A. Loria and Alan T. Gorton of National Steel's Research and Development Department, are shown in front of their latest model BOF, which refines 200-lb hot metal charges from an electric ore furnoce.

\section{MEMBERSHIP}

Metallurgical Society Members (as of June 1, 1967)

\section{BY GRADE}

Member, 6443: Associate, 1695; Junior, 2269; Student, 1850; Total, 12,357.

BY MAJOR TECHNICAL INTEREST ISD, 3472; EMD, 1424; IMD, 3970; Edu,
25; Eco, 63; Misc, 3403; Total, 12,357.

\section{Members}

Addis, Bernard F., Ithaca, N. Y. Adenis, Daniel J. P., Voreppe, France Boesenberg, Klaus, New York, N. Y. Brammer, William G., White Plains, N. Y Brown, Roy W., Falconer, N. Y. Coughlin, William P., Cleveland, Ohio Daly, Howard J., Falconer, N. Y'. Eyre, Oswin D., Ashland, Ky.

Fletcher, William C., Fairview Park, Ohio Haffner, Julius D., Corpus Christi, Texas Hanson, Charles $\mathbf{K}$., Salt Lake City, Utah Harbin, Hugh P., Chicago, III.

Hitt, James G., Pittsburgh, Pa.

Hogberg, Carl H., Upland, Calif.

Holmberg, Ulf T., Akers Styckebruk, Sweden Hulton, Frank J., Youngstown, Ohio Ikeda, George M., Hamilton, Ont., Canada Ingersoll, Richard G., Lorain, Ohio Kress, Edward S., Peoria, IIl

Logerot, Jean-Marie R., Voreppe, Franc Mack, John J., Columbiana, Ohio Marty, Warne C., Emeryville, Calif. McAulife, Donald ${ }_{j}$, Spokane, Wash. Meadows, Delmar $\mathrm{R}$. Bhiladelphi $\mathrm{Pa}$. Meadows, Delmar R., Philadelphia, Pa. Meyer, Henry L., Willoughby, Ohio Morken, Robert E., Watertown, Wisc. Nicholas, Howard B., El Paso, Texa Paine, Frederick, Chicago, IIl. Porte, Richard A.. Helena, Mont. Porter, Ronald, New Kensington, Pa. Reed, Clifford J., Hamilton, Ont., Canada Rist, Andre, Maizieres-les-Metz 57. France Roberts, Henry E., Philadelphia, Pa. Robertson, James W., Hamilton, Ont., Canada Rothrock, Russell W. Chicago, Ill Rushworth, William H., Philadelphia, Pa. Sano, Kokichi, Nagoya, Japan Siegfried, Jack A., Aurora, IIl Synder, Harold G., Warren, Ohio Syre, Robert P., Voreppe, France Teskey, George W., Cucamonga, Calif Trickett, Darrell L., Douglas, Ariz.
Urban, Richard F., Sparrows Point, Md. Wicke, W. R., Fontana, Calif. Wiginton, Eugene B., Massena, N. Y. Worrick, Robert L.., Sparrows Point, Md Yeh, Hun-chiang, Corning, N. Y. Zelle, Alexander'S., New York, N. Y.

\section{Associate Members}

Alexander, Frank A, Worcester, Mass. Clark, Leonard R., Oakville, Ont., Canada Fulton, Robert B., New York, N. Y. Given, William E., Detroit, Mich. Maldeis, Lewis F., Hinsdale, Ill. Sack, John L., Trenton, Pa. Sutton, Charles D., Parma, Ohio Williams, Dennis L., Birmingham, Ala. Zook, James R., Saxonburg, Pa.

\section{Junior Members}

Boone, Thomas F., Jr., Monaca, Pa. Dadisman, Gary L., Stamford, Conn. Gosselin, Pierre, Montreal, Que., Canada Kenney, Patrick T., Steubenville, Ohio Landsittel, Donald A., York, Pa. Paquette, Gerean E., Indianapolis, Ind. Russell, Robert O., Brooklyn, Ohio Sargent, Gordon A., Pittsburgh, Pa.

\section{CHANGE OF STATUS}

Associate to Member

Bieling, Carl R., Palmerton, $\mathrm{Pa}$

Durdaller, Cornelius G., Riverton, N. J. Shore, John R., Copper Cliff, Ont., Canada Smith, Albert B., Brigham City, Utah

\section{REINSTATEMENT-CHANGE OF STATUS}

Junior to Member

Moraes, George S., Gov. Valadares, M. G., Brazil

Joint Student to Junior

Karlyn, David A., Bethlehem, Pa.

Wilkomirsky, Igor A., Concepcion, Chile

\section{REINSTATEMENT}

\section{To Member}

Sabol, Frank P., Salem, Ohio

Shapland, James T Malem, Ohio

Skapski, Adam, Lagos, Nigeria

To Assoclate Member

Hollister, Douglas, Saginaw, Mich Jones, Edwin M., Baldwin, Md.

To Jnnior

Klaas, Peter F., Brackenridge, $\mathrm{Pa}$

\section{SPECIAL REINSTATEMENT}

To Member

Lewis, William E., Pittsburgh, Pa

To Junior

Worcester, Anthony W., Herculaneum, Mo.

\section{OBITUARIES}

\section{James Ryan}

James Ryan passed away on May 25, 1967, at his home in New York City. He was employed by AIME as Chief Shipping Clerk from 1943 until his retirement in 1959 . It was in his capacity as Assistant Convention Manager that "Jim" was well known to Institute members and those who regularly attended AIME conventions. During that time, his warm and friendly personality and his willingness to help with problems made many friends for the Institute. His genial presence will be missed by his host of friends.

\section{Ralph Henry Waddington}

Ralph Henry Waddington, 66 senior vice-president of The International Nickel Co. of Canada, Ltd. died June 10, 1967, at Lenox Hill Hospital, New York City. Mr. Waddington was a member of the company's advisory committee, and a vice-president, director, and member of the executive committee of The International Nickel Co., Inc. its U.S. subsidiary. He was also a director of Phillips Cables Ltd. Brockville, Ontario. An author of several published papers on copper refining and production, $\mathrm{Mr}$. Waddington was a member of AIME and the Committee of EMD of the $\mathrm{Ca}$ nadian Institute of Mining and Metallurgy, Sudbury, Ontario.

\section{L-D STEELMAKING AT MID-1967}

\section{(From page 10)}

pensate for hot metal shortages These auxiliary fuels can increase scrap consumption to the $50 \%$ level The fuel cost and time lost must be weighed against savings in cost of metallics and the need for ingots. Different conditions, requirements, and unit costs will lead to different answers in various plants. Separate facilities for preheating scrap with L-D Process waste heat or purchased fuel appear to be attractive under some conditions. Further studies and plant trials of these proposed techniques are needed.

In 13 years, L-D steel production in the U. S. has grown from an insignificant tonnage to the point where L-D will shortly displace the open hearth as the largest single steel producing process. The steady growth is based upon the excellent steel quality produced at favorable capital and operating costs. Increase in furnace size and an increasing versatility of metallic charge and types of steels that can be made have and will contribute much to the growth in L-D steelmaking.-End 